\title{
Dicotyledons.
}

“POLYPETALÆ.”

1. Thalamifloræ. (Including the apetalous Curvembryeæ, Micrembryeæ, and "Ordines anomali" and the Euphorbiaceæ and Urticaceæ, etc., of the Unisexuales.)

2. Discifloræ. (Including the apetalous Daphnales and the Juglandaceæ and Cupuliferæ, etc., of the Unisexuales.) 3. Calycifloræ. (Including the apetalous Aristolochiacex and Cytinaceæ). GAMOPETALÆ.
1. Heteromeræ.
3. Inferæ. University of Nebraska, Lincoln.

\section{Proceedings of Section G, A. A. A. S., Madison meeting.}

The American Association for the Advancement of Science convened in Madison, Wis., Thursday, August 17, 1893, and continued in session until the succeeding Tuesday. The following account is an outline of the addresses, papers and discussions before the section of botany, in the order in which they were presented.

\section{Thursday afternoon, August 17.}

The address of Vice-President C. E. Bessey upon Evolution and Classification was given before the Section of Botany at the a ast four o'clock, occupying one hour. An abstract of the address is printed in the preceding pages of this number.

The Section Fiday morning, August i 8.

President Bessey in called to order at 10:30 o'clock, Vicetary pro tem., with the chair, and B. T. Galloway as secre8 of papers began about forty persons present. The read1. GEO. F. A Than at once.

Mording. F. ATKINSON: Photography as an instrument for orificial cultures. - In the characters of micro-organisms in graphing plate culture usual method of lighting for phost, and in case of very the finer characteristics are usually
age is throughourent colorless organisms the 
top of the culture dish with an opaque screen the light is admitted only through the sides of the dish, and the object is thus photographed by reflected, instead of transmitted light. In this way very clear and minute details are obtained. Many fine photographs illustrating the method and its superiority to the usual method were shown.

The paper was discussed by Messrs. Galloway and Lasché. The author stated that he used Petri dishes, and that he considered the method most serviceable in differentiation.

2. G. F. AtKInson: Symbiosis in the roots of Ophioglossea.- In examining the roots of Botrychium Virginianum attention was called to masses of yellowish protoplasm located at definite points in the cortical parenchyma. From them threads extended to the outside, branching profusely in connection with the masses. Examination of large sets of Botrychium and Ophioglossum from all over the world revealed these structures in all. As root-hairs are not found in the Ophioglosseæ, it was suggested that this fungus was of great service in the work of absorption, and that probably this habit prevails in all Ophioglosseæ.

Discussed by Messrs. Smith (Erwin F.) and Swingle.

3. B. T. Galloway: Observations on a rust affecting the leaves of the Fersey or scrub pine. - A full description of the rust (Coleosporium Pini) was given, and the course of its development, especially the conditions and time of its transformations were fully described. Infection only takes place when the leaves are tender, from one-fourth to one inch long, and is usually confined to a period not exceeding two weeks.

In the discussion Professor Kellerman said that the Jersey pine (Pinus Virginiana) was abundant in southern Ohio, from near Columbus southward, and was associated with the pitch pine (P. rigida). He had not found the fungus on the former species in that state, but it was common upon the pitch pine throughout the region. Professor MacMillan mentioned an unusual case of hypertrophy due to such a parasite, observed in Minnesota, in which trees twenty to thirty years old only attained the height of a man, the whole tree becoming a kind of witch's broom.

4. W. J. Beal: Prophylla of Graminea.-These structures were described, using corn and oats as examples. With 3 view to discovering their value as a diagnostic character, 150 species belonging to fifty-six genera were examined. The 
conclusion was reached that while the lengths of prophylla hold some relation to the lengths of sheaths, the character of the apex is of chief service in classification, varying as it does from acuminate to bilobate. Such distinctions are sometimes specific, sometimes generic.

Discussed by Mr. Swingle, who suggested that prophylla show an adaptive character in the protection of young branch buds.

5. Charles R. BARnes: On the food of green plants.A discussion of various nutritive processes, suggesting the proper application and restriction of the terms "digestion" and "assimilation," claiming that the true food of plants was not the "food" of ordinary reference, and proposing the applicafion of the term "photosyntax" to the construction of carbon compounds under the influence of sunlight. [The paper will appear in full in the Botanical GazETTE.] Discussed by Messrs. Britton, Smith (E. F.), Swingle and VlacMillan.

\section{Friday afternoon, August is.}

6. J. Christian Bay: A new infection needle for the study flower plants. - A pointed wire, about six inches long, bent tround at one end to form a handle, and sharpened at the The disc is thrust through a metal disc, an inch in diameter. g dust and as a screen to prevent contamination from fallquid cultur germs when transferring infection to or from 7. G. F. A of micro-organisms.

buction of the sporon: Comparative study of the structure and The nature of thangia of ferns in the dispersion of spores. pring cells, lip annulus in various ferns was described, the scussed, and cells, and connective cells in each case being tese regions in thention called to the function of each one of ras also raised reference to scattering spores. The question "omplete" and "in to the proper application of the terms 8. BYRON "incomplete" in reference to the annulus. tanical work. HALSTED: The Solandi printing applied to ainglass in an ordine object to be reproduced is placed upon th Aristo, or otherdinary photographic printing frame, backed usual way of int is fixed with " "hyng a photographic print. When the the, and thus beconypo," it is made transparent with keropositives may becomes a negative from which any number 
leaves, sections of wood, and all kinds of thin semitransparent objects, including drawings and book illustrations. Dried leaves may be made sufficiently transparent by immersion in kerosene. If the object is moist, like fresh sections of fleshy tubers and roots, a sheet of mica can be laid between the object and the sensitive paper. Many beautiful examples of the diversified application of the process were shown. (The name is a fanciful compound of Sol-and-I.)

Discussed by Mrs. E. G. Britton, W. A. Kellerman and A. B. Seymour, who described photographic methods which they had used. The last had found two sheets of glass clamped together, when copying from bound books, quite as efficient as the printing frame, thus overcoming the necessity of cutting out the leaf.

9. N. L. BRITTON: Present aspects of the nomenclature question.-The paper was presented by request and consisted simply of a statement of the different views held in recent times, with no attempt to discuss their relative merits. W/ith reference to genera, the various positions as to the date of their recognition were grouped as follows: (I) Pre-Linnæan (naturally subdividing into those who would recognize genera from the earliest possible date, and those who would carry them back as far as Tournefort), (2) 1735 , (3) 1737 , (4) 1753 , (5) those who would use a more recent limitation. As to species, the two views are represented by those who would recognize binomials before the time of Linnæus, and those who would date them entirely from 1753 .

Discussed by Mr. E. L. Greene, who did not contend for pre-Linnæan binomials, but for the practice of crediting such names as Linnæus adopted from former authors to the respective authors. Mr. Seymour called attention to the fact that this method was in use in quoting the names used by Fries, although in this case the authorities cited were all subsequent to Linnæus.

IO. T. A. Williams: Lichens of the Black Hills.-A list was submitted containing eighty-three species and varieties, and the paper read considered only the subject of distribution. Of the eighty-three species forty-five are rock forms, eight are tree forms, twenty-one are earth forms, the remainder occupying combined localities. Comparisons were made with the lichen's of eastern Nebraska and those of Idaho and the Yellowstone Park region as published in the report of the 
Hayden Survey for 1872 . The conclusion was reached that the Black Hills lichens are of northern mainly subalpine character, and while more closely allied to the Rocky Mountain flora, are intermediate between that and the flora of eastern Nebraska. The varying preponderance of tree, rock, and earth forms was attributed to certain geological and climatic conditions.

II. J. Christian BAy: The bibliography of American botanical literature.-Attention was called to the advantages which would come from the publication of an index of American writings. Mr. Bay instanced the great value of the index of chemical literature conducted under the auspices of the Association. He offered the suggestion that Section G (Botany) appoint a committee to undertake the work. Several members discussed the subject, but all thought that
there was need of taking more time to fully consider the mat-
ter.

12. Douglas H. Campbell: Notes on the development of Marattia Douglasii. - The material for study was obtained curing the author's recent visit to Hawaii. It was claimed that the study further strengthened the view that the eusporangiates are the primitive forms. Although the complete history of the prothallia was not made out, that of the sex organs was obtained. The antheridia in structure most nearunder side, and in of Equisetum. The archegonia are on the upward growth and in development the embryo retains its direct remains almost a year, conting the base of the plantlet probably for sporophyte is continuing to do vegetative work after the archegonium is independent. The development of the the archegonium was discussed, and the transition between vgrested. The of bryophytes and that of pteridophytes primitive nature of whole structure was taken to indicate the te nearest form of Marattia, and the author regarded it as Pproaching to the liverworts yet examined, especially Discussed the Anthoceroteæ.

Gron.

13. M. B. THOMAS: The roots of orchids. - In the absence 14. L. H. PAMMer was read by title.

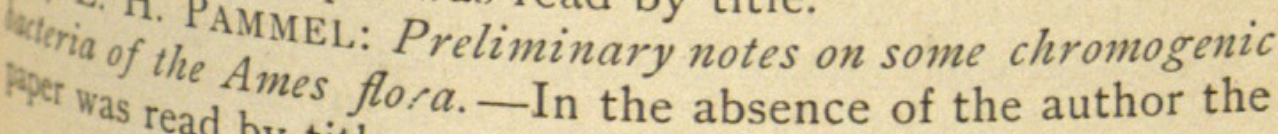


I5. B. T. GaLloway: Results of some recent work on rust of wheat.-In the absence of the author the paper was read by title.

\section{Monday morning, August 21.}

16. Theobald Smith: Further observations on the fermentation tube with special reference to anaerobiosis, reduction and gas production. - The different forms of the group of Bacillus coli produce gas when glucose is present in the culture medium, and in about equal amounts and equal rapidity. They have a varying behavior toward other sugars, however. The introduction of potash shows that about one-third of the gas produced is carbon dioxide, and the remainder of the gas is explosive, being probably hydrogen. Methylene blue put into the fermentation tube will be decolorized by the growth of the germs, but when mixed with air the fluid becomes colored again. The classification of bacteria into those causing alkaline and those causing acid reaction of the medium is not tenable, as these changes depend upon the nutritive constituents of the medium.

Mr. Lasché stated that he had found what he took to be a loss of albuminoids during such fermentation, and that no sugar was withdrawn; but that he was not yet prepared to defend this view.

I7. JoHN G. JACK: The fructification of Funiperus.Much uncertainty of statement existing concerning the length of time involved in fructification, the author studied J. Virginiana, J. Sabina, var. procumbens, and J. communis. He found that the fruit matured in one, two, and three years, in the order given. The morphology of the so-called "ovule" was also discussed. [The paper will be published in full in the GAZETTE.]

18. S. G. WRIGHT: The minute structure and development of the motile organ in the leaf of the red-bud. - An historical sketch of the subject was given and the anatomical structure of the pulvinus. The leaf begins to rise at three $A$. M., reaches a maximum at nine A. M., then falls, reaches 3 second maxium at two P. M., and then falls until at ten A. M. it reaches its full "sleeping" position. The arrangement of tissues in petiole and pulvinus was described. The pulvinus was said to be a development of parenchyma cells about the petiole, corresponding in time and method of cell-division to the mesophyll cells. All the tissues of the pulvinus are 50 arranged as to secure movement with the least possible expenditure of energy. 


\section{Monday afternoon, August 2 I.}

19. ERwin F. Smith: Two new and destructive diseases of cucurbits. - The first disease was observed in melons in Michigan, and is produced by a parasitic Alternaria, which was separated and cultivated upon agar-agar. Artificial infection was obtained by sowing the spores from the pure cultures. It produces large brown spots on the foliage, and has been called "rust." Although very destructive to melons, it does not appear to affect cucumbers. The second disease attacks cantaloupes and cucumbers, and is specially characterized by a sudden wilting of the foliage. Much of this wilting is due to cutting off the water supply from the parts beyond by the disease extending into the stem. It is produced by bacteria, which have been separated, and artificial infection produced. Cut stems from diseased portions, when put into moist air, exlude viscid drops filled with bacteria. The spread of the blight is associated with the puncture or eating of the plant by insects, and is most abundant in dry weather when leaf-eating insects are common. Bordeaux mixture proved wholly ineffective as a preventive.

The paper was discussed by Messrs. Arthur and Jones.
20. Conway Mreventive.

20. CONway MACMILlan: Preliminary statement concerning botanical laboratories and instruction in American universities and colleges. - Circulars were sent to all American unirestities and colleges, but the result was not entirely satisin others the informast no information could be obtained, sketched the information was vague. The author rapidly colleges from which courses and equipment in the various a remarkable which information had been obtained, showing ras stated that the in in the presentation of botany. It about three million united herbaria of the country represented braties from million specimens, and the united botanical lithe colleges could to 250,000 volumes. Broadly speaking, of botanical instruction: that offered by Gray's "I (I) those which do such work as loners; (2) those which's "Lessons" and the "analysis" of a few and Martin method which simply study types, after the Huxley 3) those with well, and have little or no botanical tendency; rases of botanical activeloped courses in all the various In consequencal activity.

Rted in by Mess the discussion which followed, partici- 
man, Britton and others, a resolution was passed requesting the Commissioner of Education to publish a monograph on the subject, to be prepared by Professor MacMillan.

A motion was also passed for the appointment of a committee to report at the next annual meeting of the section concerning some feasible way by which the section might use its influence in securing better botanical instruction in secondary schools. J. M. Coulter, D. H. Campbell, and N. L. Britton were appointed.

2I. Byron D. HALSTED: The shrinkage of leaves in drying.-Contact photographs of fresh leaves, with the leaf from which they were taken dried and mounted at one side, were exhibited. These showed the exact amount of shrinkage in each instance, which was often surprisingly large:

Mr. Kellerman thought the specimens were more shrunken than usual in herbarium specimens. Mr. Swingle thought the matter an important one in connection with transpiration experinents, in which the measurement of the area of the leaf is often deferred until it is dry. Mr. Jack spoke of using cotton to fill under rigid stems in the press, in order to make the leaves dry smooth and flat.

22. J. H. PILlsBuRY: On the quantitative analysis of the colors of flowers and foliage.- In the absence of the author the paper was read by title.

\section{Tuesday morning, August 22.}

23. S. M. TRACY: Distribution of the Graminea in the United States. - There are I I 2 genera in our territory. The distribution of the more important species, both indigenous and introduced, was traced and maps were shown.

24. N. L. BRITTON: A consideration of species based upon the theory of evolution. - The earth's flora was comparatively uniform to the end of the carboniferous period, and nearly as much so up to the close of the cretaceous. The segregation into various floras has thus taken place in comparatively recent times. This should make one hesitate in calling closely related forms one a variety of the other, rather than two incipient species.

Mr. Coville thought that for the proper advancement of systematic botany closely related forms should receive ample consideration. Whether it is possible to consider forms which do not intergrade as good species, and those which do as varieties, must yet be determined by working botanists. 
25. Elizabeth G. Britton: A revision of the genus Physcomitrium.-Physcomitrium pyriforme of the Manual is not P. pyriforme of Europe, but is P. turbinatum, which proves to be our most widely diffused species. An interesting new species is also described from California under the name P. sphrotheca. Instead of six species in the United States, there are probably nearly double that number. Florida forms of this genus are probably referable to three distinct species.

Mr. Barnes thought the separation of $\mathrm{P}$. turbinatum from P. pyriforme well taken.

26. W. T. Swingle: Cephalurus mycoidea and Phyllosiphon sp., two parasitic alge new to North America. - The latter of these algæ was gathered in the Dells of the Wisconsin river, three days before (Aug. I 9 th), and heretofore known only from a few places in Europe. It forms pale spots upon the leaves of Arisæma, and is probably widely distributed. The alga is a genuine parasite, living within the tissues of the leaf. The suggestion is made that this habit may explain one way in which fungi have been derived from algæ without having passed through aquatic forms. The first alga mentioned is a parasite upon Magnolia, and has been found in this country before by lichenologists, but not reported.

\section{Tuesday afternoon, August 22.} 27. FREDERICK V. COVILLE: An analysis of the condi-
tions affecting the distribution of plants. - The environmental
conditions of heat, light, plants, when reduced to their lowest terms, are Mr. MacMillan, food, air and mechanique.

tional factors, in thought it would be well to include evolunot provided including the energy of the plants, which are tention to the in the classification. Mr. Swingle called atdistribution. important part played by fire in determining fed as an ultimate Coville explained that this was not classialso said that under mechaniquen, as used by MacMillan, was included 28. J. C. Aque.

of uripe seeds. ARTur: Deviation in development due to the use about weakness. - It was shown that immature seeds bring than usual to die in the seedlings, causing a greater number that is never fullyefore becoming established, a lack of vigor of the reprod fully recovered, and an increased development Paratively greater fruitage. It was pointed out that such 
changes could also be brought about by any agency that lowered the vitality of the plant.

Discussed by Messrs. Bolley and MacMillan. [The paper will be published in full in the American Naturalist.]

29. W. T. SWINGLE: The principal diseases of citrous fruits now being studied at Eustis, Fla.-A trouble characterized by wilting shows well at a distance, but the microscope gives no additional information. It is thought to be due to some physiological check to transpiration. Mal di goma is a common disease connected in some way with a lack of proper respiration at the roots of the tree. "Die back" is a disease marked by a great variety of symptoms. The name is due to the usual dying back of the ends of the branches. Fruit and leaves are also affected. It is known to be increased by excess of nitrogen in the soil. A local disease of less importance than the preceding causes corky excrescences upon the fruit.

30. P. H. Rolfs: A sclerotium discase of plants.-Especially affects tomato, potato, egg-plant and melons, but has been found in seventeen species belonging to widely different orders. Sclerotia are abundantly formed in the stems near the ground, which give rise to mycelium on culture media, but not to spores. The relationship of the fungus has not been determined.

3i. Elizabeth G. Britton: Ulota Americana Mitten and Orthotrichum Americanum Beauv. - Dealt altogether with the tangle of synonymy in which these names are involved.

32. L. H. Pammel: Notes on Roestelia pyrata.

33. L. H. PAMMEL: Crossing of cucurbits.

34. L. H. PAMmel: A case of poisoning by the wild parsnip, Cicuta maculata. title.

In the absence of the author these papers were read by

\section{Proceedings of the Botanical Club, A. A. A. S., Madison meetıng.}

FIRST SESSION, FRIDAY, AUGUST I8, 9 A. M.

The Club was called to order by Vice-president W. A. Kellerman, the president, W. P. Wilson, and Secretary, T. H. McBride, both being absent. Mr. W. T. Swingle was 

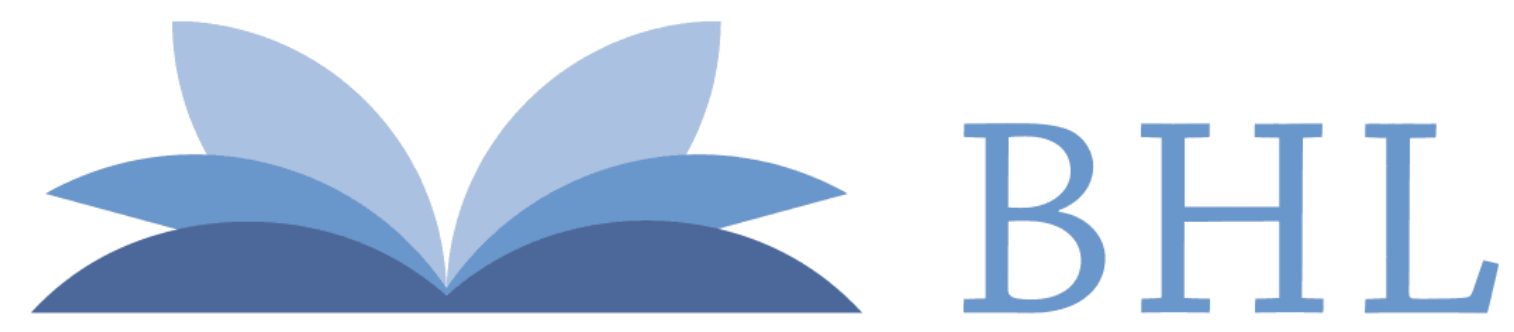

\section{Biodiversity Heritage Library}

1893. "Proceedings of Section G, A. A. A. S., Madison Meeting." Botanical gazette 18(9), 333-342. https://doi.org/10.1086/326967.

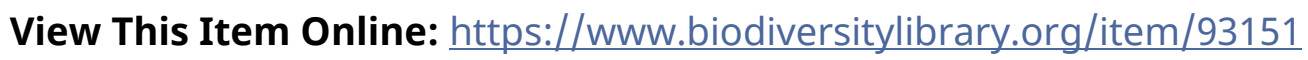

DOI: https://doi.org/10.1086/326967

Permalink: https://www.biodiversitylibrary.org/partpdf/222294

\section{Holding Institution}

Missouri Botanical Garden, Peter H. Raven Library

\section{Sponsored by}

Missouri Botanical Garden

\section{Copyright \& Reuse}

Copyright Status: Public domain. The BHL considers that this work is no longer under copyright protection.

This document was created from content at the Biodiversity Heritage Library, the world's largest open access digital library for biodiversity literature and archives. Visit BHL at https://www.biodiversitylibrary.org. 